\title{
Sygdommens rum
}

Tidsskrift for Forskning i Sygdom og Samfund

Nr. 18, 2013 


\title{
Tidsskrift for Forskning i Sygdom og Samfund
}

\author{
Nr. 18: Sygdommens rum
}

(c) 2013 forfatterne og udgiverne.

Redaktion:

Mette Bech Risør (ansv.), Forskningsenheden for Almen Praksis, Universitetet $i$ Tromsø

Torsten Risør, Det Sundhedsvidenskabelige Fakultet, Universitetet $i$ Tromsø

Gitte Wind, Institut for Kultur og Samfund - Antropologi, Aarhus Universitet

Ann Dorrit Guassora, Forskningsenheden for Almen Praksis, Københavns Universitet

Susanne Reventlow, Forskningsenheden for Almen Praksis, Københavns Universitet

Rikke Sand Andersen, Forskningsenheden for Almen Praksis, Aarhus Universitet

Claus Bossen, Institut for Medie- og Informationsvidenskab, Aarhus Universitet

Helle Ploug Hansen, Helbred, Menneske og Samfund, Syddansk Universitet

Peer review: Foretages af et tværvidenskabeligt panel bestående af bl.a. læger, antropologer, filosoffer, historikere, psykologer, politologer og sociologer.

Proof: Stine Haslund Jønsson

Layout og prepress: Stine Haslund Jønsson

Tryk: Werk Offset, Højbjerg.

Udgiver:

Foreningen Medicinsk Antropologisk Forum,

Afd. for Antropologi og Etnografi, Aarhus Universitet, Moesgård, 8270 Højbjerg.

Bestilling, abonnement, henvendelser og hjemmeside:

Tidsskrift for Forskning i Sygdom og Samfund.

Afd. for Antropologi og Etnografi, Aarhus Universitet, Moesgård, 8270 Højbjerg

Tirsdag kl. 10-13, tlf. 87162063,

Email: sygdomogsamfund@hum.au.dk

Hjemmeside og artikler online:

ojs.statsbiblioteket.dk/index.php/sygdomogsamfund/index

ISSN (tryk): 1604-3405

ISSN (online): 1904-7975

Tidsskriftet er udgivet med støtte fra Forskningsrådet for Kultur og Kommunikation.

Formål:

Tidsskrift for Forskning i Sygdom og Samfund er et tværfagligt tidsskrift, der tager udgangspunkt i medicinsk antropologi. Tidsskriftet har til formål at fremme og udvikle den forskning, der ligger i grænsefeltet mellem sundhedsvidenskab og humaniora/samfundsvidenskab. Tidsskriftets målsætning er at fungere som et forum, hvor disse fag kan mødes og inspirere hinanden - epistemologisk, metodisk og teoretisk - i forskellige forskningssammenhænge. Tidsskriftet formidler den debat og teoretiske udvikling, der foregår i de voksende faglige samarbejds- og forskningsinitiativer, der udspringer af dette grænsefelt. Tidsskriftet henvender sig til alle med interesse for forskning i sygdom og samfund og i særlig grad til sundhedsmedarbejdere i forsknings- og undervisningssammenhæng med forbindelse til tværfaglige miljøer.

Aims and scopes

The Journal for Research in Sickness and Society is an interdisciplinary journal which has a theoretical background in medical anthropology. The aim and purpose of the journal is to promote and develop research in the borderland between the health sciences and the humanities/the social sciences. The goal of the journal is to function as a forum in which these disciplines may meet and inspire each otherepistemologically, methodologically and theoretically. The journal conveys the debate and theoretical development which takes place in the growing collaboration and research initiatives emerging from this borderland. The journal addresses all with an interest in research in sickness and society and especially health professionals working with education and/or research in interdisciplinary institutions. 


\section{Indhold}

Torsten Risør

Introduktion 5-11

Regner Birkelund

Det æstetiske indtryks betydning for sundhed, sygdom og velvære 13-20

Tenna Doktor Olsen Tvedebrink, Anna Marie Fisker \& Poul Henning Kirkegaard

Sygdommens spiserum: Har arkitekturen en overset eller glemt betydning her? 21-38

Rikke Nygaard, Mia Brandhøj, Camilla Berg Christensen \& Bent Egberg Mikkelsen

Måltidets Rum - rum for sundhedsfremme? 39-65

Hanne Bess Boelsbjerg

Det hellige rum: Sjælesorgssamtaler på hospitalet 67-86

Iben Emilie Christensen \& Sofie Ilsvard

Sygdom og selvopfattelse på tværs af rum 87-111

Birgitte Schepelern Johansen E Katrine Schepelern Johansen

At tæmme nydelsen - en analyse af den rumlige indretning af en dansk heroinklinik 113-134

Anne Kathrine Frandsen

Environmental qualities and patient well-being in hospital settings 135-158

Abstracts in English 159-163

Forfatterliste $165-167$

Skrivevejledning $\quad 168-170$

Beskrivelse af nr. 19171 


\title{
Sygdom og selvopfattelse på tværs af rum
}

\section{Iben Emilie Christensen \& Sofie Ilsvard}

\author{
KORA \\ Institut for Folkesundhed, Aarhus Universitet \\ ibenemilie@hotmail.com,sofieilsvard@gmail.com
}

Christensen, I. E. \& Ilsvard, S. (2013). Sygdom og selvopfattelse på tværs af rum. Tidsskrift for forskning i Sygdom og samfund, nr. 18, 87-111.

Artiklen undersøger betydningen af fysisk-rumlige omgivelser $i$ forhold til sygdoms- og selvopfattelsen hos mennesker med svære fysiske handicap og funktionsnedsættelser, der er visiteret til vederlagsfri fysioterapi som del af deres behandling. Studiet tager afsat $i$ et fænomenologisk-hermeneutisk feltarbejde, hoor det centrale omdrejningspunkt er deltagernes subjektive oplevelser og udbytte af vederlagsfri fysioterapi, ligesom vi undersøger deltagernes måde at håndtere og integrere fysioterapiklinikkens institutionelle ramme som en fast bestanddel af hverdagslivet. Deltagerne træner for at opretholde et givent funktionsniveau eller forhale forringelser, og der er ofte tale om livslange træningsforløb. På trods af, at deltagerne livslangt frekventerer og opholder sig i fysioterapiklinikker, er det sparsomt med viden om deltagernes oplevelser heraf. Artiklens formål er derfor at skabe indsigt $i$ deltagernes oplevelser og erfaringer med at opholde sig og træne i fysioterapiklinikken og undersøge rummets betydning i relation til deltagernes selvopfattelse. I den empiriske analyse anlægges et relationelt perspektiv, eftersom deltagerne italesætter deres sygdoms-og selvopfattelse, dels afhængigt af hoor de befinder sig, dels af deres subjektive opfattelse af rum. I den forbindelse argumenteres for, at rummets betydning forst træder frem, når vi kigger på tværs af rum. Derfor udledes det, at fysioterapiklinikken, hvori sygdom behandles og praktiseres, ikke repræsenterer et 'sygdommens rum', men af deltagerne opleves som et tiltrængt frirum fra sygdom, hoor de føler sig som 'almindelige mennesker'. I modsætning 
hertil står det private hjem og det offentlige rum, som nærmere repræsenterer 'sygdommens rum', da det er her, handicap og funktionsnedsættelser skaber barrierer for det sociale liv, og her grænserne mellem det normale og afvigende defineres.

Artiklen omhandler forholdet mellem fysiske rum, sygdom og selvopfattelse. Den tager udgangspunkt $i$ et feltarbejde, gennemført $i$ hjemmene og $i$ en fysioterapiklinik blandt mennesker med svære fysiske handicap og funktionsnedsættelser, som er ordineret vederlagsfri fysioterapi på hold som en del af deres behandling. Gennem analyse af deltageres rumlige oplevelser og erfaringer fra fysioterapiklinikken, det private hjem og det offentlige rum anlægges et relationelt perspektiv, som bidrager til en helhedsforståelse af, hvordan selvopfattelsen hos mennesker med svære fysiske handicap og funktionsnedsættelser udfolder sig forskelligt afhængigt af, dels hvor de befinder sig, dels af deres subjektive opfattelse af rum. I den forbindelse argumenteres for, at fysiske rammer såvel som deltagerne på træningsholdene skal forstås som relationelle konstruerende aktører herfor. Når vi undersøger menneskers selvopfattelse på tværs af rum, kan det paradoksalt nok udledes, at fysioterapiklinikken, hvori sygdom behandles og praktiseres, ikke repræsenterer et 'sygdommens rum', men af deltagerne opleves som et tiltrængt frirum fra sygdom, hvor de føler sig som 'almindelige mennesker'. I modsætning hertil står det private hjem og det offentlige rum, som nærmere repræsenterer 'sygdommens rum', da det er her, handicap og funktionsnedsættelser skaber barrierer for det sociale liv, og her grænserne mellem det normale og afvigende defineres. Ydermere indkredser artiklen, hvordan deltagerne integrerer fysioterapiklinikkens institutionelle ramme som en fast bestanddel af hverdagslivet $\mathrm{i}$ form af et 'arbejde', hvilket indikerer rummets normalitetsskabende funktion.

Feltnote: "Rummet er stort og inddelt i forskellige sektioner. Receptionen ligger til venstre, når man kommer ind af hoveddøren. Det er også i den ende, hvor de mindre rum er til individuel behandling og fysioterapeuternes kontor. Til højre for indgangen er et større træningsområde med forskellige maskiner, såsom motionscykler, løbebånd, crosstrainer, romaskine og benpresmaskine. I en anden del af lokalet er et større gulvareal med træningsredskaber som vippebrædder til balancetræning, måtter, bolde, sjippetove, ribber og vægte, der står langs væggene. Der står også en briks i det ene hjørne. Væggene er malet i en solgul farve. Der er udsigt til søen fra den ene side af rummet, som man straks retter opmærksomheden mod. Til den anden side er udsigt til byens gågade, byliv og butikker. Det er vores første dag i træningsrummet. Som jeg (observatøren red.) står på crosstraineren, har jeg 
udsigt ud over gågaden. Lige før klokken slår 8.30, begynder 5 kvinder, som alle går på det samme træningshold, at ankomme til dagens træning. Tre af kvinderne er ældre. En af kvinderne går med krykker, og en anden er også tydeligvis gangbesværet. Langs en af væggene i træningsrummet er en skænk, hvor alle kvindernes træningsprogrammer ligger på. Der står desuden en kande med vand og fem glas med hver af kvindernes navne på. Glassene ser hjemmelavede ud, der er malet mønstre og farverige blomster på dem. Det virker helt hjemligt på en måde. Der er også et musikanlæg, der i øjeblikket spiller Rod Stewart. Kvinderne går hver især i gang med dagens træning".

Ovenstående feltnoteuddrag stammer fra et feltarbejde i en fysioterapiklinik og beskriver den fysiske indretning, stemning og deltagerne. Formålet med vores tilstedeværelse i fysioterapiklinikken og i deltagernes private hjem var at få et indblik i hverdagen hos mennesker, der lever med svære fysiske handicap og funktionsnedsættelser som følge af progressiv sygdom - og som er ordineret vederlagsfri fysioterapil af deres praktiserende læge som led i deres behandling. Den eksisterende litteratur om vederlagsfri fysioterapi ${ }^{1}$ har primært interesseret sig for ordningens form og visitationsprocedurer, hvorimod det er sparsomt med viden om, hvilken betydning vederlagsfri fysioterapi har for de mennesker, som er visiteret til ordningen. Formålet med feltarbejdet var derfor at undersøge, hvilken betydning vederlagsfri fysioterapi har for deltagerne, idet der ofte er tale om livslange forløb i fysioterapiklinikken, hvor deltagerene træner flere gange ugentligt for at opretholde et funktionsniveau eller forhale forringelser. I fysioterapiklinikken mødte vi Bente på 58 år med paraplegi, som forklarer, hvordan vederlagsfri fysioterapi indgår i hendes hverdag: "Træningen er en del af mit liv. Jeg går til individuel fysioterapibehandling om mandagen, ridefysioterapi om tirsdagen og så går jeg til holdtræning om onsdagen. Jeg har også på et tidspunkt gået til svømning i et varmtvandsbassin". Bente bruger mange timer ugentligt på at træne, så hun holder sig i gang. For langt størstedelen af de mennesker vi fulgte i fysioterapiklinikken, er vederlagsfri fysioterapi ikke blot blevet en del af deres hverdag, men i højere grad ér det deres hverdag.

\section{Rummet, kroppen og bevægelser}

Det mennesketomme træningsrum ligner en ældre udgave af et fitnesscenter med de gængse maskiner og redskaber. De fysiske omgivelser afslører ikke umiddelbart, at der er tale om en fysioterapiklinik, hvor mennesker med alvorlige kroniske 
lidelser træner for at vedligeholde funktionsniveau eller forhale forringelser. For mennesker, der er ordineret vederlagsfri fysioterapi, er fysisk aktivitet forbundet med besvær, og mange er derfor stærkt afhængige af hjælpemidler som kørestol, el-crosser, stok eller rollator for at komme omkring. I rummet ligger der en implicit opfordring til bevægelse, mens det modsatte gør sig gældende i de individuelle behandlingsrum, hvor disse giver anledning til at holde kroppen i ro grundet briksens centrale placering i rummet. Som det fremføres af Gulløv og Højlund, kommunikerer rummets genstande, materialer og dets indretning om rummets anvendelsesmuligheder, opgaver og formål, men også om dets brugere, der forventes at være til stede i rummet (Gulløv og Højlund, 2005). Træningsrummet får først karakter af en fysioterapiklinik i det øjeblik, deltagerne træder ind i rummet, og de bliver derved i høj grad medbestemmende for, hvordan rummet defineres.

Hver deltager følger et individuelt træningsprogram som er blevet udformet af fysioterapeuten, hvor der tages højde for diagnose, handicap og funktionsnedsættelsens fremskredenhed. Træningsprogrammerne består typisk af en række øvelser på forskellige maskiner eller ved hjælp af forskellige redskaber, som deltagerne skal lave et bestemt antal gange eller et bestemt antal minutter. De individuelle træningsprogrammer er nedskrevet på et stykke papir, som ligger fremme under hver træning. Ud for hver øvelse kan deltagerne eller fysioterapeuten notere, hvordan det går fra gang til gang, således at det er muligt at følge med i deltagerens udvikling ud fra en række kvantificerbare målinger. Træningsprogrammerne er med til at organisere deltagernes træning og er styrende for, hvor i rummet deltagerne opholder sig. De forskellige motionsmaskiner og redskaber kan defineres som aktivitetsstationer udvalgt af fysioterapeuten, der alle tjener forskellige formål. Ved hjælp af træningsprogrammet guides deltagerne rundt til forskellige gøremål i rummet, som markerer, hvad der er vigtigt for den enkelte deltager. Rummet er inddelt i forskellige zoner, hvortil der er knyttet forskellige forventninger og adfærd. I området med forskellige motionsmaskiner træner deltagerne efter forskellige mål i relation til deres individuelle træningsprogram. Maskinerne er tæt placeret på hinanden, og deltagerne kan se hinandens resultater og tider, hvilket for nogle af deltagerne bidrager til et konkurrenceelement og til 'hvis han kan, så kan jeg også'-mentalitet.

I området med det større gulvareal er bolde og ribber placeret langs væggene. Gulvområdet giver anledning til mere 'fri leg' blandt deltagerne, idet de kan tage de redskaber frem, som de ønsker at benytte. Det er også i denne del af rummet, at fysioterapeuten på forhånd opstiller forhindringsbaner for bestemte deltagere 
og derved skaber en bestemt omgivelse med en bestemt hensigt og mål for øje. Følgende feltnoteuddrag stammer fra en træningstime i fysioterapiklinikken:

"Ud over gulvet har fysioterapeuten Mads spredt 6-7 lange skumgummi-stænger. Det ligner en slags forhindringsbane. Grethe kommer herind, det er hende, der skal bruge de ting, Mads har lagt ud på gulvet. Grethe har haft en blodprop i hjernen og skal lære at kontrollere sine ben. Hun starter med at gå op på trampolinen, derefter ned på gulvet og så henover de blå skumgummi-fiduser. Hver gang hun er nået over til den anden side, hvor enten stolen eller briksen er, sætter hun sig og holder en kort pause. Mens Grethe er i gang med at øve på 'forhindringsbanen', hvor hun balancerer på en række redskaber og skal gå hen over nogle ting, holder Mads øje med, hvordan hun klarer det. 'Det går da godt' siger han, og han tilføjer 'du er da blevet bedre til at balancere, selvom jeg kan se, at det er noget, du gerne vil have overstået'. 'Ja det er godt nok', svarer hun".

Fysioterapeuten lægger redskaber ud på gulvet i en bestemt rækkefølge, som virker begrænsende for deltagernes udfoldelsesmuligheder og medbestemmelse for træningsforløbet. Forhindringsbanen leder Grethe rundt i rummet på en bestemt måde og fungerer derved som en "tavs pædagogisk medhjælper", der disciplinerer hende til at bevæge sig på forudbestemte måder (Gulløv \& Højlund, 2005). Deltagernes individuelle træningsprogrammer fungerer på samme disciplinerende vis og anviser således kroppen til at udføre de samme øvelser og gøre de samme bevægelser. Samspillet mellem rum og krop bevirker således, at kroppen opfører og bevæger sig på bestemte måder, og der skabes gentagelser og rutiner, som indgår i deltagernes kroppe som en tavs og indlejret viden om rummets bevægelsesrammer.

\section{Felt og metode}

Som fremført af sociolog Anselm Strauss (1975) betyder ændrede livsbetingelser, at kroppen indgår i andre situationer end hidtil, og nogle regimer bliver derfor afløst af nye regimer med andre regler og forskrifter. I forlængelse heraf argumenterer vi for, at vederlagsfri fysioterapi er det regime, som er omdrejningspunkt og anvisningsgivende for deltagernes hverdagsliv. En meget stor del af deltagernes tid bruges på vederlagsfri fysioterapi, og som skrevet er der ofte tale om livslange træningsforløb. Med denne artikel indskriver vi os i feltet 'sygdommens rum' ved at undersøge, hvilken betydning fysisk-rumlige omgivelser har i forhold til selvopfattelsen hos mennesker med svære fysiske handicap og funktionsnedsættelser. 
Studiet af sygdom og selvopfattelse på tværs af rum tager sit afsæt i et fænomenologisk-hermeneutisk feltarbejde. Det centrale omdrejningspunkt for feltarbejdet har været deltagernes subjektive oplevelser og udbytte af vederlagsfri fysioterapi og deres måde at håndtere og integrere vederlagsfri fysioterapi som en del af hverdagslivet med kronisk sygdom. Artiklen baserer sig på et feltarbejde, udført fra september 2010 til februar 2011 i en privatpraktiserende fysioterapiklink i en provinsby i Danmark og i hjemmene hos 12 mennesker, som er ordineret vederlagsfri fysioterapi som en del af deres behandling. Derudover er der foretaget et fokusgruppeinterview med tre fysioterapeuter. Feltarbejdet i fysioterapiklinikken foregik på tre forskellige træningshold, som af fysioterapeuterne blev omtalt som henholdsvis 'kvindeholdet', 'parkinsonsholdet' og 'det blandede hold'. Kvindeholdet bestod af kvinder med forskellige diagnoser, parkinsonsholdet bestod af både mænd og kvinder med diagnosen Parkinsons syge, og endelig bestod det blandede hold af mænd og kvinder med forskellige diagnoser. Det blandede hold og kvindeholdet trænede to gange ugentligt à halvanden times varighed, mens parkinsonsholdet trænede en gang ugentligt á en times varighed. Deltagere på træningsholdene lever enten med svære fysiske handicap eller funktionsnedsættelser som følge af Parkinsons syge, neurologisk skade, apopleksi, spastisk lammelse, paraplegi og scoliose og er i alderen 39 til 75 år.

Vores feltarbejde i fysioterapiklinikken bestod af fire ugers deltagende observation. I begyndelsen af feltarbejdet havde vi en åben og eksplorativ tilgang til felten, som senere udviklede sig til mere fokuseret observation, hvor vi valgte at lægge vægt på blandt andet fysioterapiklinikkens indretning, holdenes gruppedynamik, relationer og interaktion. Under feltarbejdet havde vi også mange løst strukturerede samtaler med deltagere og fysioterapeuter. Den deltagende observation var valgt med henblik på at indgå aktivt i felten og mærke den fysiske træning på egen krop. Vi var dog opmærksomme på, at vi ikke kunne deltage i træningen på lige vilkår med de andre deltagere, da vi ikke har svære fysiske handicap eller funktionsnedsættelser. Vi fik i stedet tilrettelagt vores træning efter tænkte problematikker, såsom knæ- og rygskade, således vores træningsprogrammer var målrettede og udformningsmæssigt mindede om de andre deltageres træningsprogrammer. Deltagerobservationen har derfor været med til at skabe en større forståelse for de rutiner og rytmer, der er forbundet med vederlagsfri fysioterapi. I hjemmene hos de 12 deltagere havde feltarbejdet karakter af semistrukturerede interviews samt observationer af hjemmenes indretning. Formålet med de individuelle interviews har været at lade deltagerne komme til orde med deres oplevelser og erfaringer i forbindelse med vederlagsfri fysioterapi samtidig 
med, at vi kunne spørge ind til konkrete situationer, vi havde observeret under træningen. Ydermere har vi gennem interviewene fået forståelse og indsigt i hverdagslivet hos mennesker med svære fysiske handicap og funktionsnedsættelse og deres sygdomshistorier. Endelig har besøgene i de private hjem givet os et uvurderligt indblik i, hvordan fysisk-rumlige omgivelser og indretning på forskellig vis har betydning for deltagernes selvopfattelse. Det var også under interviewene, vi blev opmærksomme på, at forholdet mellem fysiske rum, sygdom og selvopfattelse kun kan forstås ved at anlægge et relationelt perspektiv, hvorfor deltagernes oplevelser af dels fysioterapiklinikken, hjemmet og det offentlige rum først gav mening, når vi kiggede på tværs af rummene. Interviewene blev optaget på diktafon og varede fra tre kvarter til to timer og blev efterfølgende transskriberet. I enkelte tilfælde deltog deltagernes ægtefæller også i interviewene. Fokusgruppeinterviewet med de tre fysioterapeuter havde til hensigt at belyse tankerne bag vederlagsfri fysioterapi ud fra et fagprofessionelt synspunkt. Fysioterapeuterne er med til at skabe rammerne for vederlagsfri fysioterapi, og deres måde at agere på som fysioterapeuter er med til at konstruere deltagernes oplevelser. Som eksempel herpå vil vi fremhæve fysioterapeuternes benævnelse af det diagnosespecifikke hold som 'parkinsonsholdet'. Derudover benævner fysioterapeuterne de mennesker, som er ordineret vederlagsfri fysioterapi som 'patienter', fordi de er henvist til vederlagsfri fysioterapi af praktiserende læge og lider af alvorlige kroniske lidelser. Sådanne kategoriseringer kan, som det blandt andet er blevet fremført af Ian Hacking (1991), bidrage til yderligere sygeliggørelse og utilsigtede negative konsekvenser. For ikke at anvende potentielt sygeliggørende kategoriseringer benævner vi, afhængigt af konteksten, de mennesker, som er ordineret vederlagsfri fysioterapi, som 'mennesker med svære fysiske handicap eller funktionsnedsættelser' eller 'deltagere'. Grunden til, vi anvender termen 'deltagere', er, at de deltager på et hold sammen med andre. Desuden var der under vores feltarbejde ingen af deltagerne selv, der betegnede sig som patienter, men tværtimod som deltagere på et hold. Da artiklens analytiske omdrejningspunkt er sygdom og selvopfattelse på tværs af rum, har vi fundet det hensigtsmæssigt at anvende erfaringsnære begreber som mennesker og deltagere om artiklens centrale aktører.

I det følgende undersøger vi sygdom og selvopfattelse på tværs af rum gennem en løbende dialog mellem vores observationer og tolkninger, informanternes udsagn og en bred vifte af indsigt fra teoretikere. Selvom feltarbejdet tog afsæt i en fænomenologisk-hermeneutisk tilgang, har analysen ikke udelukkende været styret heraf. Tværtimod har vores eksplorative tilgang givet anledning til at 
applicere andre teoretiske tilgange, som rækker ud over den fænomenologiskehermeneutiske tilgang, eksempelvis Bruno Latours aktør-netværks-teori.

\section{På kroppens og sygdommens betingelser}

Deltagerne i fysioterapiklinikken har det til fælles, at de lever med svære fysiske handicap og funktionsnedsættelser. Under træningen er deltagerne derfor afhængige af fysioterapeutens hjælp. Det kan være i forbindelse med at indstille maskiner eller finde redskaber frem - alt sammen praktiske foranstaltninger, som deltagernes fysik afgrænser dem fra selv at kunne. Den fysiske træning er hård og intens, deltagerne sveder, puster og presser sig selv. Basale øvelser kræver koncentration og refleksion. Den dysfunktionelle krop er en udfordring; det er kroppen, der kæmpes med, men også imod. Dette modsætningsforhold bliver italesat af deltagerne, som ikke oplever mærkbare forbedringer i forbindelse med træningen. Derimod oplever de tydelig forskel, hvis de udebliver fra træningen. Det bliver udtrykt af deltageren Bente på følgende måde: "Jeg kan ikke mærke nogen forbedringer, men hvis jeg ikke har været der, så kan jeg godt mærke, at det er længe siden, og så skal det hele trænes op igen. Det er jo vedligeholdende fysioterapi".

I fysioterapiklinikken møder vi Iris på 65 år. Iris pådrog sig en neurologisk skade efter et fald på en trappe i sit hjem, som betyder, at hun efter flere års genoptræning stadig har behov for mange hjælpemidler i hverdagen som bl.a. krykker og en kørestol. Under interviewet med Iris fortæller hun, hvorfor fysioterapiklinikken er anderledes end et fitnesscenter:

"Jeg kan ikke bare gå hen på et hvilket som helst motionscenter og træne. Selvom jeg godt ved, hvordan redskaberne skal bruges, så ville jeg ikke kunne. Jeg skal have min fod bundet fast med elastikker, når jeg skal køre på den der cykel, og sådan er der forskellige ting, som jeg simpelthen er nødt til at have hjælp til, og hvis du er ude at træne på et almindeligt motionsinstitut, eller hvad det nu hedder... Jamen der kan jeg jo ikke forvente, at der står en træner hos mig hele tiden".

For Iris er det afgørende, at en fysioterapeut er til stede i rummet, således hun kan få hjælp til at placere kroppen korrekt på de forskellige maskiner og redskaber og derved opnå det bedst mulige udbytte af træningen. Det er ikke blot i træningsrummet, at deltagerne har brug for hjælp. Selve indtrædelsen i rummet kan være en udfordring, idet træningen foregår på 1. sal, hvilket er en forhindring for dem som bruger krykker, rollator eller kørestole. Deltagerne er derfor nødsaget til at 
tage trappen eller benytte elevatoren i bygningen for at komme ind i fysioterapiklinikken. Derudover er det besværligt at åbne dørene ind til selve træningsrummet. Flere deltagere beskriver derfor, at det, på grund af sygdommens progression, er en begrænset periode, de endnu kan indtræde i rummet, da der er for mange forhindringer og udfordringer forbundet med rummets placering på 1. sal.

Den fysisk rumlige kontekst deltagerne indgår i i fysioterapiklinikken, er bundet op på deres dysfunktionelle kroppe. De har kun adgang til rummet på grund af deres krop. Samtidig er kroppen også det, der begrænser deltagerne, idet bevægelser og handlinger i vid udstrækning sker på kroppens og sygdommens betingelser. Vi har tidligere argumenteret for, at der er begrænsede bevægelsesmuligheder i rummet, da kroppen følger skemalagte træningsplaner og forhindringsbaner, som griber styrende og adfærdsreguleringerne ind i forsøget på at ændre den dysfunktionelle krop. Fysioterapiklinikken kan derfor ses som en 'handlingsanvisende social agent', som på en og samme tid hjælper og presser deltagerne til at vedligeholde deres funktionsniveau og forhale forringelser (Latour, 1992; Kirkeby, Gitz-Johansen \& Kampmann, 2005).

\section{Rummets sociale betydning}

"Et eller andet sted så føler jeg mig på lige fod med dem. Jeg føler ikke, de taler ned til mig, for det kan man nemlig godt opleve, når man er handicappet, fordi så er man jo anderledes på en eller anden måde".

Bente taler her om, hvordan hun oplever forholdet til de andre deltagere på holdet og fysioterapeuterne. Mange af deltagerne oplever, at træning på hold bidrager til følelsen af at indgå i et fællesskab, som er trygt og fordomsfrit. Til trods for at handicap og funktionsnedsættelser fremstår meget synligt i fysioterapiklinikken og er det, der binder deltagerne sammen i rummet, er følelsen af at være anderledes ikke til stede i netop dette rum. Deltagerne indgår i et fællesskab i fysioterapiklinikken, som de sjældent oplever andre steder. Deltagerne kan betegnes som 'interessepartnere', der er beskrivende for fællesskabets opståen og omdrejningspunkt (Falk, 2005). 'Interessepartnere' fordi træning er en nødvendighed for at forhale forringelser af funktionsniveau, og yderligere og måske endnu vigtigere, som 'interessepartnere', der indgår i et fællesskab med andre mennesker i lignende situationer. Sociolog Zygmunt Bauman betegner et sådant fællesskab som et 'knagefællesskab', hvor individet midlertidigt kan 'hænge' individuelt oplevede erfaringer eller gøremål på 'knager', der udgøres af forskellige former for 
interesser, for herefter at tage dem ned igen og placere dem andetsteds, hvis det pågældende fællesskab ikke længere opfylder individets behov (Bauman, 2002). I den forbindelse tilbyder det rumligt og tidsligt afgrænsede træningsfællesskab deltagerne et ståsted, hvor de kan føle tryghed, sikkerhed og tilfredsstillelse i hverdagslivet uden at blive defineret som 'afvigere' - som eksempelvis Bente beskriver, at mennesker med handicap ofte kan opleve.

Foruden den rent fysiske træning er et af formålene med vederlagsfri fysioterapi at facilitere et rum, hvor mennesker med handicap og funktionsnedsættelser har mulighed for at møde ligesindede og derved få glæde af hinandens oplevelser og erfaringer i forbindelse med deres situation og sygdom (Sundhedsstyrelsen, 2008). Hvis vi kigger nærmere på den interaktion, der fandt sted i fysioterapiklinikken mellem henholdsvis deltagerne imellem og deltager-fysioterapeut, er det dog bemærkelsesværdigt få samtaler, der relaterer sig til sygdom. Louise på 39 år med multipel sclerose fortæller, hvad deltagerne snakker om under træningen, og hvorfor det netop ikke er om handicap og funktionsnedsættelser:

"Det er bare nogle ganske almindelige hverdagsting, som man snakker om, og så får man gjort lidt sjov ud af det i stedet for, at det hele skal være så alvorligt. Vi snakker jo næsten aldrig sygdom. Andet selvfølgelig end hvis der er én, der ikke har det godt, så spørger vi da, hvordan han eller hun har det, men ellers så snakker vi om alt muligt andet. Nogen snakker om, hvilke bøger de lige har læst eller ja, det er mange ting - alt andet end sygdom (...) For mange, dér fylder deres sygdom jo rigtig meget, og så gider de ikke, at når de kommer til fysioterapeut, så skal det også handle om det. Man gider det ikke".

Blandt deltagerne på holdene er der en fælles stiltiende accept af, at der ikke tales om sygdom i fysioterapiklinikken under træningen. Grunden til at deltagerne på holdene sjældent taler om sygdom, handicap og funktionsnedsættelser, forstår vi som et mere eller mindre bevidst forsøg på at undgå, at sygdom bliver altoverskyggende i deres hverdagsliv. Samtaleemnerne i fysioterapiklinikken mener vi indgår som del af en normaliseringsproces, hvori deltagerne forsøger at være som andre 'almindelige' mennesker. Det er ikke til at 'høre', at samtalerne udfolder sig blandt en gruppe af mennesker, som har fysiske handicap og funktionsnedsættelser tilfælles, og de kunne i princippet lige så godt udspille sig på et gymnastikhold, en arbejdsplads, bingoklub eller lignende. Deltagernes fællesnævner kunne lige så vel være noget andet, men den specifikke livsomstændighed, i form af handicap og funktionsnedsættelser, binder dem sammen i fysioterapiklinikken. 
Selvom deltagernes handicap og funktionsnedsættelser er den livsomstændighed, der udgør grundlaget for fællesskabet, og den rumlige kontekst fællesskabet udspiller sig i, i høj grad er bundet op på deltagernes dysfunktioner, er indholdet for fællesskabet altså ikke kun defineret herved. Noget tyder på, at fysioterapiklinikken - dens indretning, dens aktører og diskursen heri - ikke er medvirkende til en yderligere sygelig- eller patientliggørelse. Tværtimod anses fysioterapiklinikken af deltagerne i den bogstaveligste forstand som et 'rum med plads til forskel' og som et frirum fra handicap og funktionsnedsættelser. I forlængelse heraf argumenterer vi for, at deltagerne investerer både manifeste og latente interesser i rummet. Manifest interesse forstået som den fysiske træning og det vedligeholdende aspekt, og latent interesse forstået som, at træningsfællesskabet bidrager til en normaliseringsproces. Fysioterapiklinikken repræsenterer derfor et fysisk rum, hvori deltagerne ikke udelukkende reduceres til og kategoriseres som syge eller handicappede.

Fysioterapiklinikkens udformning, dens indretning og interiør har afgørende betydning for de sociale relationer og aktiviteter, der eksisterer deltagerne imellem. Lis på 68 år med Parkinsons syge forklarer under interviewet, hvorfor hun og de andre deltagere på træningsholdet ikke har etableret tætte sociale relationer, selvom de træner sammen to gange ugentligt og har gjort det $\mathrm{i}$ mange år.

"Vi kunne sagtens få en snak i gang, hvis man havde et opholdsrum, der indbød til, at man satte sig ned. Så kunne man måske godt sidde der et kort stykke tid og få en kop kaffe og en lille snak, fordi jeg får jo ikke snakket med dem om følelser. Hvis det var en mulighed, så synes jeg absolut, det var en fordel med en lille kaffestue eller et sted, hvor man kunne sætte sig og snakke lidt sammen. Der kunne jo sagtens stå et lille bord".

Ifølge Lis opfordrer fysioterapiklinikken som rum ikke til, at deltagerne imellem skaber tætte relationer på grund af fraværet af bestemte materielle genstande som 'et opholdsrum' eller 'et lille bord'. Som Latour skriver, kan socialitet og handlinger ikke forstås som uafhængige af de rumlige omgivelser, de indgår i. Omgivelserne skal derimod betragtes som 'non-humane' medskabende aktører for de typer af relationer, der udvikles mellem de 'humane aktører', deltagerne (Latour, 1996a; Latour, 1996b). Det lille bord som 'non-human aktør' kunne i Lis' optik være med til at ændre den rumlige tilrettelæggelse og derved skabe mulighed for, at deltagerne taler mere sammen. Vi mener dog ikke, at rummets rumlige organisering vil kunne ændre deltagernes fælles stiltiende accept af, at der ikke tales om sygdom i fysioterapiklinikken, da dette er et forsøg på at distancere sig fra, at syg- 
dom bliver altoverskyggende i hverdagen. Derimod mener vi, at inkluderingen af en simpel genstand som et lille bord i rummet kunne bidrage til, at deltagerne taler endnu mere om hverdagslivets almindeligheder, hvilket stemmer overens med vores argument om samtalernes normaliserende funktion. Det fysiske rum er derfor medbetingende for det sociale rum, og for hvilke sociale aktiviteter, der anses for hensigtsmæssige og mulige, men det definerer dem ikke.

\section{Rummet som arbejdsplads}

Langt størstedelen af de mennesker, vi mødte på fysioterapiklinikken, var udenfor arbejdsmarkedet. For nogle har det været en naturlig del af livet at gå på pension. For andre har pension været nødvendig, som følge af handicap eller funktionsnedsættelsernes stigende invalidering. Dette har medført store identitetsmæssige og sociale problemstillinger. Flere deltagere giver udtryk for, at en hverdag uden job og kollegaer eller i det hele taget ikke at have noget at stå op til kan være en udfordring.

67-årige Rasmus med sclerose fortæller, at dagligdagen uden et arbejde har vendt op og ned på hans hverdagsliv. Før var dagligdagen præget af faste rutiner, som er svære at erstatte i en hverdag, hvor et arbejde ikke længere indgår. Han oplever at have oceaner af tid, og hverdagen er præget af kedsomhed og til tider ensomhed. Rasmus forsøger at indarbejde faste rutiner for at skabe stabilitet i sin hverdag. Han forsøger at stå op på det samme tidspunkt hver dag og benytter træningen i fysioterapiklinikken som hverdagens faste holdepunkt. For Rasmus er omorganisering af tid og planlægning blevet centrale omdrejningspunkter i dagligdagen:

"Det må ikke begynde at flyde ud eller bytte om på dag eller nat - det går slet ikke, så jeg har nogle helt bestemte vaner. For hvis jeg ikke gør det, så tror jeg, tingene begynder at flyde for meget, hvis ikke der er nogle bestemte rammer, man følger eller er indenfor. Hvis ikke jeg har nogle bestemte rutiner, så er jeg bange for, at jeg siger 'jamen så skidt med det, det betyder ikke så meget'. Men hvad er der så tilbage efterhånden? Man skal lige passe på!".

Flere af deltagerne giver udtryk for, at det er problematisk at forlade arbejdsmarkedet ufrivilligt. De dysfunktionelle kroppe er ikke længere adgangsgivende til arbejdspladsens rum, hvorfor følelsen af ikke længere at bidrage med noget til samfundet for manges vedkommende betyder en ændret selvopfattelse. For mange af deltagerne betyder det, at hverdagslivet på én og samme tid opleves som kaotisk og trivielt, og noget der skal udfyldes med aktiviteter. 
Under feltarbejdet blev vi opmærksomme på, at flere deltagere italesætter træningen i fysioterapiklinikken som et 'arbejde'. Vi tolker arbejds-termen som en ubevidst strategi til at kompensere for og udfylde følelsen af det tomrum, som fraværet af et ordinært arbejde giver. Ifølge sociolog Alfred Schutz (2005) er mennesket underlagt to former for tid: 'ydre' og 'indre' tid ('durée'). Den indre tid er en bevidsthedsstrøm af indre oplevelser og begivenheder, der griber ind i hinanden, og som hverken er opdelt i fortid, nutid eller fremtid. I stedet vil oplevelserne flyde sammen, da nutidige oplevelser kan forbindes med fortidige begivenheder og minder. Ligeledes kan fortiden opfattes og forbindes med fremtidens begivenheder (Bech-Jørgensen, 2005). Den ydre tid er derimod kronologisk tid efter klokketiden, hvor begivenheder er tidsmæssigt struktureret i en rækkefølge (Schutz, 2005). De to forskellige former for tid er usammenlignelige, men kan forbindes, idet den indre tids begivenheder, ved hjælp af refleksionen, kan blive projiceret over i den ydre tid (Bech-Jørgensen, 2005). Alle mennesker har både den indre og den ydre tidsopfattelse som en integreret del af bevidstheden, men dét der afgør, hvorvidt individet oplever tiden som henholdsvis mere ydre eller indre, afhænger af de konkrete situationelle omstændigheder, der omgiver det enkelte individ (Jørgensen, 2006). Når deltagerne anser træningen i fysioterapiklinikken for et arbejde, indikerer det, at de forsøger at omorganisere den indre tids flydende tilstande over i den strukturerede ydre tid.

For Grethe er det altafgørende at møde i fysioterapiklinikken til tiden, for som hun udtrykker det: "Hvis man skulle møde på arbejde, så skulle man også møde til tiden". Ydermere gjorde Grethe et særligt indtryk, da hun til hver træning var nyvasket og fint klædt på, og mere lignede én, der var på vej på arbejde end til træning, hvilket følgende feltnoteuddrag illustrerer: "Grethe er klædt i, hvad jeg ville kalde hverdagstøj. Cowboybukser og en lyserød rullekravebluse, og så har hun mange guldsmykker på. Hun virker meget fin i forhold til, at hun er her for at træne". Det er vigtigt for Grethe at se velsoigneret, anstændig og præsentabel ud selvom, at træningen vil få hende til at svede. Grethes omtale af vederlagsfri fysioterapi som et arbejde og hendes påklædning synes i harmoni med, at Grethe i fraværet af et ordinært arbejde tillægger træningen denne betydning.

Da vi interviewer 74-årige Keld med Parkinsons syge, spørger vi ham om, hvorvidt han er tilfreds med, at træningen i fysioterapiklinikken foregår om formiddagen. Hertil svarer Keld: "Jeg ved ikke, om det sådan sidder i en fra arbejdslivet, at det er om formiddagen, man arbejder, og så holder man fri om eftermiddagen". Ved at identificere træningen som det arbejde han tidligere udførte om formiddagen, undgår han netop at komme udenfor den indre tids flydende tilstande. For 
nogle mennesker kan det måske lyde tillokkende at være udenfor den kvantificerede tids pres, men vi argumenterer for, at deltagerne oplever den indre tids flydende tilstande som uholdbar, ustabil og ustruktureret, hvorfor træningen tilgås som et arbejde for at undgå dette.

Tager vi udgangspunkt i fysioterapiklinikken som et objektivt rum, repræsenterer den et institutionelt rum, hvor deltagere og fysioterapeuter er bundet sammen om et fælles formål: At forhale forringelser eller vedligeholde et givent funktionsniveau. Som objektivt rum får fysioterapiklinikken på grund af dens indretning (træningsmaskiner og redskaber), formål (behandlingsforløb) og dens aktører (mennesker med svære fysiske handicap eller funktionsnedsættelser og sundhedsfagligt personale) karakter af at være 'sygdommens rum'. Imidlertid indeholder en sådan beskrivelse af fysioterapiklinikken også en betydelig 'rumblindhed'. I det ovenstående har vi med udgangspunkt i deltagernes subjektive udsagn erfaret, at fysioterapiklinikken netop ikke opleves som 'sygdommens rum'. Tværtimod opleves den af mennesker med svære fysiske handicap og funktionsnedsættelser som et tiltrængt frirum fra handicap og funktionsnedsættelser. Nogle af deltagerne anser endda fysioterapiklinikken som et 'arbejde' og de andre deltagere som 'kollegaer'. Ved at kompensere for det identitetstab eksklusionen fra arbejdspladsens rum kan forårsage, mener vi, at deltagerne over tid forstår og integrerer fysioterapiklinikken som deres nye arbejdsplads, som de strukturerer deres hverdagsliv omkring. I denne henseende indgår fysioterapiklinikken som et normaliserende element i deltagernes hverdagsliv, hvilket betyder, at deltagerne går på 'arbejde' ligesom såkaldt 'almindelige' mennesker. Anvender vi Latour's begreber, oplever vi, at fysioterapiklinikken forstået som 'nonhuman' aktør har differentiel betydning for forskellige 'humane' aktører, blandt andet for os som observatører og for deltagerne. Derfor kan det samme rum, som det er fremført af Tonboe (1993), indgå forskelligt i forhold til forskellige aktører "uden dog at have mytiske kræfter".

\section{På tværs af rum}

Deltagernes oplevelse af fysioterapiklinikken er del af en større social virkelighed, og netop derfor giver 'rumopfattelsen' ikke mening, når den studeres isoleret. Vi vil derfor anlægge et relationelt blik på de fysiske rum, mennesker med fysiske handicap og funktionsnedsættelser frekventerer, da deres oplevelse af fysioterapiklinikken kun giver mening, når den studeres i den kontekst, den forekommer i; nemlig på tværs af rum (Antoft \& Salomonsen, 2007,; Gilje \& Grimen, 2004; Ton- 
boe, 1993). Vi vil nu fokusere på deltagernes private boliger og det offentlige rum. I forbindelse med vores feltarbejde blev vi hurtigt opmærksomme på, at netop disse rum spiller en væsentlig rolle, da de af deltagerne ofte blev italesat, inden vi havde spurgt ind til dem. I modsætning til fysioterapiklinikken italesætter deltagerne deres private boliger og det offentlige rum som de steder, hvor de oftest bliver mindet om eller konfronteret med deres handicap og funktionsnedsættelser. For flere deltageres vedkommende resulterer det i negative konsekvenser for identitet og selvopfattelse, hvilket yderligere kan skabe barrierer for det sociale liv. Dette vender vi tilbage til i forbindelse med offentlige rum. For at undersøge hvordan forskellige rum påvirker mennesker med svære fysiske handicap og funktionsnedsættelser, vender vi os nu mod konkrete rumlige oplevelser og erfaringer, der, som skrevet, rækker udover fysioterapiklinikken.

\section{Hjemmet - praktik før æstetik}

Den private bolig eller hjemmet bliver ofte opfattet som et af de mest personlige rum, vi frekventerer i hverdagslivet, da vi selv har mulighed for at forme og iscenesætte det, som det blandt andet er påvist af Cuba \& Hummon (1993) og Williams (2002). Hjemmet betragtes som en identitetsmarkør, der på forskellige måder markerer, hvem vi er, vores værdier, og "hvor succesrige vi er (...) i hele vores livsprojekt" (Kristensen, 2008). Deltagernes fortællinger peger dog i retningen af, at mulighederne for at iscenesætte sig selv gennem hjem og bolig opleves som begrænsede, da indretning og valg af bolig oftest er begrundet i praktiske overvejelser frem for æstetiske. Når vi træder ind i et hjem, åbnes vores sanser og i løbet af kort tid, danner vi os de første indtryk af hjemmet. Hjemmet taler sit eget sprog, og vi begynder at afkode, hvilket slags hjem vi er trådt ind: Hvilke slags sko står fremme, er der rodet eller ryddeligt, er indretningen kreativ eller traditionel? Så snart man træder ind i et hjem, "slås tonen an" (Winther, 2005).

I forbindelse med vores feltarbejde besøgte vi deltagerne i deres private hjem. Med en enkelt undtagelse - som vi skal vende tilbage til senere - blev vi mødt af hjem, som 'fortalte', at det husede personer, som ikke var ved fuld fysisk førlighed. I entreerne talte rummet sit eget sprog: Speciallavede sko, som er nemme at få på, rollatorer, bænke og gribehåndtag var typiske objekter. Når vi fortsatte længere ind i boligen, typisk ind i køkkenet eller stuen hvor interviewene foregik, fortalte boligindretningen med dens mange hjælpemidler, at vi befandt os i hjemmene hos mennesker med svære fysiske handicap og funktionsnedsættelser. Flere deltagere fortæller da også, at handicap og funktionsnedsættelser er betingende for, hvilke 
boliger de kan gøre til deres hjem og yderligere, hvordan hjemmet kan indrettes. Flere deltagere har været nødt til at flytte til mere handicapvenlige boliger i takt med, at deres funktionsevne er blevet forringet. Især trapper, dørtrin og passager, der er for smalle til, at de kan bruge deres hjælpemidler i hjemmet, giver anledning til at flytte. Deltagerne vægter først og fremmest, at deres hjem skal være fremkommeligt, således at de selvhjulpne kan komme ind i og fungere i hjemmet.

For Bente har det været en langvarig proces at acceptere, at hendes funktionsnedsættelse begrænser mulighederne for, hvilke boliger hun kan fungere i. Derfor har Bente været nødt til at flytte to gange i takt med, at hendes funktionsevne er blevet ringere. Flytningerne beskriver Bente som en nødvendighed eller med hendes egne ord som en slags 'indrømmelser', hun har måttet gøre sig:

"Til at starte med tror man, at man kan klare alting. Der var én, der sagde til mig, at det tager 7 eller 8 år at vænne sig til at være handicappet. Og der tænkte jeg hold nu op, det kan ikke passe! Men det er altså rigtigt. Man lærer at sige "jamen det her det vil jeg bare ikke, jeg vil ikke udsætte mig for det, jeg gider ikke alle de her nederlag"'".

Først flyttede Bente med sin familie fra et toetageshus til et etplanshus. Efter oplevelsen af et 'nederlag' i etplanshuset, hvor især indrømmelsen af at hun ikke længere var i stand til at holde en stor have, blev det til endnu en flytning. Denne gang flyttede Bente ind i en mindre andelslejlighed i stueetagen, hvortil der også var have. Haven bestod af et mindre stykke jord med belægning og beplantning i krukker og var derfor stort set vedligeholdelsesfri. For Bente og andre deltagere har det været nødvendigt at flytte til boliger, der i forvejen havde en form, som passede bedst muligt til deres behov. Alligevel har samtlige deltagere lavet små justeringer i deres hjem, som bevirker, at de kan leve så normalt et liv som muligt. De fleste deltagere er desuden bevidste om, at deres progredierende sygdomme kræver, at hjemmet med tiden indrettes yderligere på kroppens betingelser eller kræver flere flytninger.

Fjernelse af dørtrin og løse tæpper beskriver deltagerne som et af de første skridt hen imod et hjem, der huser et handicappet menneske. Udover at der fjernes ting, møbler eller genstande, som kan være med til at besværliggøre eller ligefrem være farlige for den daglige færden i hjemmet, bliver der også tilføjet en række nye genstande: Håndtag i brusenichen, badetaburetter og bænke, skridsikre bademåtter, forhøjet toiletsæde, sygeseng, gangborde, ryg- og skråpuder, speciallavede lænestole og bogstøtter er alle eksempler på nogle af de hjælpemidler, som deltagernes hjem er indrettet med, foruden stokke, rollatorer, kørestole mm., der 
gør deltagerne mobile. Hjælpemidler fylder således meget i deltagernes hjem, og som Allison Williams (2002) fremfører, er det medvirkende til at hjemmet får karakter af et 'terapeutisk landskab'. På den ene side kan hjælpemidlerne og dermed også det 'terapeutiske landskab' være med til at minde deltagerne om, at de er handicappede og ikke kan udfolde sig frit fysisk, men på den anden side er hjælpemidlerne også medvirkende til, at deltagerne kan opretholde et så normalt hverdagsliv som muligt. Uanset om der fokuseres på den mere positive eller negative udlægning af hjælpemidlernes funktion, kommer vi ikke udenom, at de er synlige - hvilket i sig selv opleves som problematisk af nogle deltagere.

For Iris var tanken om de mange synlige hjælpemidler uudholdelig. For hende svarer synlige hjælpemidler i hjemmet til en unødig og ikke kærkommen sygeliggørelse:

"Man kan jo ikke løbe fra, at man er handicappet, men jeg har tænkt, at hjemmet ikke behøver være indrettet således, man kan se, at her bor en handicappet. Så hvis man ikke lige ved det, så er det ikke til at se, her bor en handicappet. Jeg burde jo have sådan en handicappet bolig, men det behøver man sgu ikke".

Iris befinder sig i en sådan økonomisk privilegeret situation, at hun sammen med sin mand har taget konsekvensen af den neurologiske skade, hun pådrog sig under en ulykke og har fået bygget et nyt hus. Huset er designet og indrettet efter, at det skal være så nemt som muligt for Iris at komme omkring i sin kørestol eller el-crosser. Samtidig er de mange hjælpemidler, som Iris er afhængig af, integreret i boligen på en sådan måde, at de nærmest er usynlige. Grundet Iris og sin ægtefælles lokale situation har det ikke været nødvendigt at gå på kompromis med valg af bolig og indretning af deres hjem. Af samme årsag har det været muligt at vægte æstetiske perspektiver i forhold til udformningen og den kreative indretning af deres hjem mindst lige så højt som praktiske perspektiver. Ovenstående illustrerer Iris' kamp mod sit handicap, som ikke skal definere hende. Netop derfor har hun forklædt sit hjem på en måde, så hverken hjælpemidler eller boligindretning opleves som en yderligere sygeliggørelse. Boligindretningen tolker vi som et udtryk for Iris' aktive valg om ikke at beskæftige sig mere end højst nødvendigt med sit handicap, for som hun siger: "Altså, det med sygdom, der når man til en vis grænse, så gider man simpelthen ikke mere".

Som Dorte Gannik (1999) foreslår, anser vi sygdomsbegrebet som en relationel størrelse, der forandres i takt med individets lokale og sociale situation, og som Gannik anskuer vi det derfor som 'situationelt' bestemt. Deltagernes lokale situation har derfor betydning for den enkeltes syn på egen sygdom og dermed 
også, hvordan hjemmets indretning påvirker forståelsen af egen sygdom. Uanset hvordan hjemmet opleves af deltagerne - fra størstedelen af dem, hvor bolig og hjem indrettes efter praktiske hensyn, til Iris som har økonomiske ressourcer til at indrette sit hjem nøjagtigt, som hun vil - kommer de ikke udenom at forholde sig til deres hjem som et rum, der skal kunne facilitere et så normalt hverdagsliv som muligt på trods af handicap og funktionsnedsættelser. Tager vi udgangspunkt i Heideggers etymologiske analyse af at 'bo', er det blandt andet defineret ved, at vi dvæler ved det vante med det formål, at vi bliver bekendte med de sammenhænge, vi er i og finder tryghed i dem (Ingold, 2000; Martinsen, 2005). Deltagerne kan dog ikke nøjes med at dvæle ved deres hjemlige omgivelser. Handicap og funktionsnedsættelser forværres typisk over tid, hvorfor deltagerne tvinges til fortsat at arbejde på at kunne dvæle - ved at tilføre hjemmet flere hjælpemidler eller lignende (Aarhus \& Ballegaard, 2010) - for igen at kunne færdes trygt i de hjemlige omgivelser. Ifølge Timothy Ingold (2000) skal hjemmet derfor forstås som en organisme med en flygtig karakter, da det kan skifte 'form' alt efter, hvilke formål det skal tilpasses efter. For nogle deltagere har 'trygheden' dog den slagside, at den kan bidrage til følelsen af patientliggørelse i eget hjem. På trods af dette oplever deltagerne et større handlerum i det private hjem set $\mathrm{i}$ forhold til betingelserne for den måde, de kan færdes på i det offentlige rum.

\section{Offentlige rum}

"Det er især folk, der ikke kender mig, de henvender sig ikke sådan til mig. Det er især hvis jeg sidder i kørestol, for så ved man ikke, "jamen er det hovedet den er gal med, eller er det kun benet?!". Folk er meget nervøse for det, og så vil de hellere lade være med at sige noget".

Uddraget stammer fra et interview med Bente, som sætter ord på det ubehag, hun ofte oplever, når hun deltager i selskaber eller lignende, hvor der er mange fremmede mennesker. Sådanne oplevelser er ikke ualmindelige blandt deltagerne, når de frekventerer steder, hvor der er mennesker, de ikke kender - hvad enten det gælder dagligdagsaktiviteter i supermarkedet eller sjældnere begivenheder som udlandsrejser. Når deltagerne færdes i det offentlige rum og anvender deres hjælpemidler, oplever de ofte at blive kategoriseret og interageret med som 'handicappede' eller 'syge', hvilket ifølge Strauss (1975) er dominerende for interaktionen. 
For Iris har det været grænseoverskridende at skulle bevæge sig ud i bybilledet ved hjælp af sine hjælpemidler, da hun oplever, at andre anser hende som "en gammel kone, der sidder på en el-crosser". Om andre mennesker reelt foretager disse kategoriseringer, har vi intet grundlag for at vurdere, og det er også mindre væsentligt. Derimod er Iris' subjektive oplevelse af, at hendes krop tillægges andre værdier i det offentlige rum, end når hun befinder sig i fysioterapiklinikken eller i sit private hjem, det centrale i denne sammenhæng. Vi ønsker at inddrage oplevelser og erfaringer med at færdes i det offentlige rum hos deltagerne for at undersøge, hvordan sygdom konstrueres forskelligt i disse rum, og hvilken betydning det har for deres selvopfattelse. For hvorfor forholder det sig således, at Iris' selvopfattelse er en anden i det offentlige rum? Ifølge sociolog Alfred Schutz (2005) er en del af forklaringen, at vi dagligt anvender typificeringer eller kategoriseringer, som beskriver enkeltstående karakteristika eller egenskaber ved en person for nemmere at kunne forstå os selv eller andre mennesker. Kategorierne 'handicappet' eller 'syg' er måder, Iris oplever, at andre mennesker forholder sig til hende på, hvilket tydeligvis repræsenterer et modstykke til kategoriseringer af det 'normale'. Selvopfattelse og identitet bliver derfor et kollektivt anliggende, som skabes og tillægges betydning i interaktionen mellem mennesker, og det er således hverken et individuelt eller indre fænomen (Jacobsen, 2007). For deltagerne betyder det, at færden i det offentlige rum kan opleves som en barriere i forhold til at opretholde et så normalt liv som muligt, da det kan være svært håndterbart at blive påtvunget og reduceret til 'sygelige' egenskaber. Ifølge deltagernes fortællinger er det ofte deres hjælpemidler, der fungerer som katalysator for sådanne miskrediterende oplevelser. Især hjælpemidlernes synlighed har en helt central betydning, ligesom også Strauss (1975) påpegede i sine studier af kronisk sygdom. Mange deltagere oplever, at deres handicap og funktionsnedsættelse blotlægges, når de medbringer deres hjælpemidler i det offentlige rum. For nogle deltagere betyder det, at de føler sig stigmatiseret, hvilket resulterer i nedsat social aktivitet udenfor hjemmet.

"Jeg går ikke ret meget ud. Jeg synes, at folk de kigger efter en. Det er mest, når jeg går alene, for ellers skulle jeg jo nok kunne gå en tur. Men jeg har ikke rigtig lysten til det. Der er jeg nok blevet lidt anderledes, for ellers har jeg jo alle dage nok kunnet gå. Men når jeg er ude at gå, så har jeg på fornemmelsen, at folk de kigger på mig”.

Ovenstående uddrag stammer fra et interview med Grethe, som efter en hjerneblødning oplever, at hun går "som en, der er fuld". Indkøb i supermarkedet, besøg ved frisøren eller gåture, som før var basale dagligdagsrutiner, kan nu være 
grænseoverskridende. Endda så grænseoverskridende at Grethe vælger at blive hjemme. Oplevelsen af den ændrede krop har influeret på Grethes spontanitet i forhold til at entrere rum og steder, som hun tidligere færdedes hjemmevant i. Lignende erfaringer har andre deltagere gjort sig i forbindelse med ferier og udlandsrejser. I det følgende fortæller Bente, hvorfor hun takkede nej til en tur til Berlin:

"Det kunne være spændende, men jeg ved jo ikke, hvordan jeg kan komme rundt dernede. Det var en togtur, og hvordan skal jeg komme op i det der tog? Toiletforholdene de ville nok være okay, og der ville hele tiden være noget, man kunne støtte sig til, så det ville nok være ok. Men hvad så med sådan noget med at bo på hotel, jamen det er måske også i orden. Men så skal man rundt og se en masse, og så skal man med bus, og man skal måske gå langt, og det er jo også op og ned af kantsten, og så skal jeg skubbes rundt i den der kørestol, jamen det vil jeg bare ikke!".

I det offentlige rum er hjælpemidler mere undtagelsen end reglen, hvilket vi mener, er med til at højne følelsen af at være anderledes eller til besvær, og netop derfor fravælger nogle deltagere konsekvent at færdes i bestemte rum. Andre har udviklet deciderede strategier for, hvordan de kan færdes i det offentlige rum uden at blotlægge deres handicap og funktionsnedsættelser og derved ikke opleve ubehag ved andres blikke, når de gør indkøb eller lignende. For flere af deltagerne betyder det, at de lader deres hjælpemidler blive hjemme eller kun medbringer dem, som de mener, får dem til at se mindst 'handicappede' ud. Iris fortæller en historie om en anden deltager på holdet, Elisabeth, som ofte tager ind til byen kun ved hjælp af sin rollator og uden sin kørestol på trods af, at kroppen er 'ødelagt' dagen efter. Det tolker vi som et forsøg på at ændre offentlighedens syn på hende fra handicappet til mindre handicappet. Elisabeth forsøger at kamuflere sine symptomer, selvom hun må betale en høj fysisk pris for det. Hun og de andre deltagere forsøger, som fremført af sociolog Erving Goffman, at manipulere omgivelsernes blik på dem med henblik på en mere fordelagtig selvrepræsentation qua 'indtryksstyring'. I Goffmanske termer forsøger deltagerne så at sige at 'passere', hvilket betegner de anstrengelser, de gør i forsøget på at skjule potentielle miskrediterende oplysninger om dem selv (Goffman, 1990a; Goffman, 1990b). Ligesom vi så det i forbindelse med hjælpemidler i det private hjem, er der også forbundet et vist paradoks ved brug af hjælpemidler i det offentlige rum, som på den ene side aflaster og kompenserer, og på den anden side begrænser og stigmatiserer. Hjælpemidlerne, der foruden i ordets bogstaveligste forstand, hjælper deltagerne, fungerer i ligeså høj grad som katalysator for en udefrakommende og påtvungen 'sygelig' fornemmelse for færden i det offentlige rum. Yderligere argumenterer vi 
for, at ovenstående er med til at understrege de mange tanker, som deltagerne gør sig om deres fysiske handicap og funktionsnedsættelser, og hvor svært det er at gøre disse forhold til en del af en 'altoverskyggende virkelighed', hvor man ikke er bevidst om de ting, man gør (Schutz, 2005).

\section{Fysioterapiklinikken - Frirum til at være menneske}

I denne artikel har vi forsøgt at tegne et billede af, hvordan selvopfattelsen hos mennesker med svære fysiske handicap og funktionsnedsættelser udfoldes og udvikles forskelligt afhængigt af forskellige fysisk-rumlige omgivelser; fysioterapiklinikken, det private hjem og det offentlige rum. I den forbindelse har vi argumenteret for, at fysiske rammer i samspil med deltagerne på træningsholdene skal forstås som relationelle konstruerende aktører. Det relationelle perspektiv hjælper os til at forstå, at deltagernes subjektive rum- og selvopfattelser først giver mening, når vi studerer dem i de forskellige kontekster de forekommer i; nemlig på tværs af rum.

Da vi under feltarbejdet trådte ind i fysioterapiklinikken som observatører, var det med en vis 'rumblindhed', der ledte os i retningen af rummets differentielle 'objektive' og 'subjektive' betydning (Tonboe, 1993). Som udefrakommende noterede og oplevede vi en række indikatorer, som pegede på, at fysioterapiklinikken i udgangspunktet kunne betegnes som 'sygdommens rum'. Dette gjorde sig gældende, da fysioterapiklinikken frekventeres af mennesker, som lever med kroniske lidelser i form af svære fysiske handicap og funktionsnedsættelser. I det samme rum modtager deltagerne hjælp og behandling af et sundhedsprofessionelt personale i form af fysioterapeuter. Desuden er deltagerne lægehenvist til vederlagsfri fysioterapi som en del af deres behandling, og som følge heraf betegnes de i fysioterapeutisk og sundhedsfagligt regi som 'patienter'. Derudover 'taler' fysioterapiklinikken et tydeligt sprog, når deltagerne træder ind i rummet, da det synligt fremgår, at de er afhængige af hjælpemidler både i mobilitetssammenhænge, men også under træningen. Som feltarbejdet skred frem, lærte vi deltagerne bedre at kende. Vi trænede sammen med dem i fysioterapiklinikken, hvilket bidrog med et uvurderligt indblik i, hvad der var på spil i rummet, og hvordan deltagerne agerede. Desuden besøgte vi deltagerne i deres private hjem og fik gennem deres fortællinger et større indblik i, hvilke andre rum de frekventerer i hverdagslivet, og hvilke oplevelser og erfaringer de har i forbindelse hermed. Ud fra deltagernes fortællinger om deres oplevelser og erfaringer af deres færden i forskellige rum, stod det klart, at vores indledende antagelse ikke holdt stik. Når vi undersøger 
deltagernes selvopfattelse på tværs af rum, kan det paradoksalt nok udledes at fysioterapiklinikken, hvori sygdom behandles og praktiseres, ikke repræsenterer et 'sygdommens rum', men af deltagerne opleves som et tiltrængt frirum fra sygdom, hvor de føler sig som 'almindelige' mennesker.

Ligesom der var en række indikatorer, der pegede på, at fysioterapiklinikken var 'sygdommens rum', når vi anskuede den som et 'objektivt rum', er der, når vi anskuer fysioterapiklinikken som et 'subjektivt rum', også en række indikatorer, der peger på det modsatte. Når deltagerne befinder sig i fysioterapiklinikken, forsøger de bevidst at undgå, at sygdom bliver omdrejningspunkt for snak og samtaler, og forsøger derimod at tale om hverdagslivets almindeligheder. I fysioterapiklinikken indgår deltagerne derfor som 'interessepartnere' i et fællesskab med andre 'almindelige' mennesker med svære fysiske handicap og funktionsnedsættelser. Følelsen af at være anderledes mindskes i miljøet, hvor handicap, funktionsnedsættelser og hjælpemidler er mere reglen end undtagelsen, og normalitetsfølelsen bliver stærkere af at tilgå træningen som et 'arbejde' og de andre deltagere som 'kollegaer'. Vi vil gerne fremhæve, at sygdom, svære fysiske handicap og funktionsnedsættelser er strukturerende for deltagernes hverdagsliv, hvorfor alt andet partout må indpasses efter dette omdrejningspunkt. Det interessante er imidlertid deltagernes forskellige oplevelses- og erfaringsmæssige 'greb' i forhold til deres tilstedeværelse i fysioterapiklinikken, som får karakter af normaliserende elementer. Dette resulterer $i$, at mennesker med svære fysiske handicap og funktionsnedsættelser, på baggrund af deres subjektive oplevelse af rummet, ubevidst formår at skabe deres egen normaliseringsproces, og som følge heraf oplever fysioterapiklinikken som et frirum til at være menneske.

I modsætning hertil står det private hjem og det offentlige rum, som nærmere repræsenterer 'sygdommens rum' for mennesker med fysiske handicap og funktionsnedsættelser, da det er her, de fysiske rammer i samspil med handicap og funktionsnedsættelser skaber barrierer for det sociale liv, og her grænserne mellem det normale og afvigende defineres. I det private hjem og i det offentlige rum bliver de ofte mindet om eller konfronteret med deres dysfunktionelle kroppe. For de flestes vedkommende er mulighederne for, hvilke boliger de kan gøre til deres hjem begrænsede, og hjemmet indrettes efter sygdommens betingelser, hvilket er med til at fremme en patologiseret selvopfattelse. Det offentlige rums fysiske rammer virker endnu stærkere patologiserende for selvopfattelsen hos mennesker med svære fysiske handicap og funktionsnedsættelser, da handicap, funktionsnedsættelser og hjælpemidler tager sig endnu tydeligere ud i denne type rum, hvor de er mere undtagelsen end reglen. I den forbindelse oplever de at blive interageret med 
og kategoriseret som 'syge' eller 'handicappede', hvilket virker stigmatiserende og for nogles vedkommende betyder, at de afholder sig fra at færdes i bestemte rum. Det subjektivt oplevede rum er derfor betingende for selvopfattelsen og dermed også for, hvordan selvopfattelsen hos mennesker med svære fysiske handicap og funktionsnedsættelser udfolder og udvikler sig forskelligt på tværs af rum.

Til sidst vil vi fremhæve fysioterapiklinikkens fysisk-rumlige ramme, som for mennesker med svære fysiske handicap og funktionsnedsættelser repræsenterer et frirum til at være menneske. For dem er det en del af hverdagens selvfølgelighed at frekventere, opholde sig og 'arbejde' i fysioterapiklinikken, selvom kroppens gentagende bevægelser i rummet stadigvæk, og formentlig altid, vil kræve refleksion. For deltagerne er det blevet en selvfølgelighed, at fysioterapiklinikken er et grundelement i deres hverdagsliv, hvilket virker befordrende for deres følelse af 'hjemlighed' i rummet, fordi: "Han [aktøren] føler sig hjemme i verden, fordi verden også er i ham" (Bourdieu, citeret fra Dovey, 2002).

Vi håber, at artiklen kan give anledning til en videre anvendelse af et relationelt perspektiv, når menneskers sygdoms- og selvopfattelse skal undersøges, da forståelsen heraf først udfoldes som et samlet hele i samspillet og i den gensidige vekselvirkning mellem krop og rum.

\section{Noter}

1: Vederlagsfri fysioterapi er en ordning der fritager brugerne for egenbetaling, og omfatter mennesker med svære fysiske handicap og funktionsnedsættelser som følge af progressiv sygdom. For begge vederlagsfri grupper gælder, at den vederlagsfri fysioterapi i udgangspunktet skal foregå som holdtræning. Formålet med ydelsen vederlagsfri fysioterapi er, at den "skal have til formål at forbedre funktioner, vedligeholde funktioner eller forhale forringelser af funktioner" (Sundhedsstyrelsen, 2008). Desuden beskriver Sundhedsstyrelsen (2008), at målsætningen for vederlagsfri fysioterapi er, at (1) Give adgang til fysioterapi for at forbedre funktioner, vedligeholde funktioner eller forhale forringelse af funktioner hos voksne og børn med et varigt svært fysisk handicap eller en funktionsnedsættelse som følge af progressiv sygdom. (2) Etablere fysioterapi i form af holdtræning i dertil egnede lokaler/bassiner/- institutioner efter nærmere bestemmelser. (3) Give adgang til fysioterapi for personer med progressive sygdomme tidligt i sygdomsforløbet. 


\section{Litteratur:}

Aarhus, R., Ballegaard, A., S. (2010). Negotiating boundaries: Managing Disease at Home. CHI, April 10-15, 171-180.

Antoft, R., \& Salomonsen, H., H. (2007). Det kvalitative casestudium - introduktion til en forskningsstrategi. In R. Antoft, M. H. Jacobsen, A. Jørgensen \& S. Kristiansen (Eds.), Håndværk og horisonter. Tradition og nytænkning i kvalitativ metode (pp. 29-58). Odense, Syddansk Universitetsforlag.

Bauman, Z. (2002). Fællesskab - en søgen efter tryghed $i$ en usikker verden. København: Hans Reitzels Forlag.

Bech-Jørgensen, B. (2005). Alfred Schutz og hverdagslivet - indledning ved Birte BechJørgensen. In Schutz, A. Hverdagslivets sociologi. En tekstsamling. København: Hans Reitzels Forlag.

Cuba, L., \& Hummon, D. (1993). A place to call home: Identification with dwelling, community and region. The Sociological Quarterly, 34, 111-131.

Dovey, K. (2002). The Silent Complicity of Architecture. In J. Hiller \& E. Rooksby (Eds.), Habitus, a Sence of Place. Aldershot: Ashgate.

Falk, J. (2005). Ferdinand Tönnies. In H. Andersen \& L. B. Kaspersen (Eds.), Klassisk og moderne samfundsteori (pp. 59-71). København: Hans Reitzels Forlag.

Gannik, D. E. (1999). Situationel Sygdom. Fragmenter til en social sygdomsteori baseret på en undersøgelse af ryglidelser. København: Samfundslitteratur.

Gilje, N., \& Grimen, H. (2004). Samfundsvidenskabernes forudsætninger - Indføring i samfundsvidenskabernes videnskabsfilosofi. København: Hans Reitzels Forlag.

Goffman, E. (1990A).Stigma - Notes on the Managenment of Spoiled Identity. Penguin Books.

Goffman, E. (1990B). The presentation of self in everyday life. Penguin Books.

Gulløv, E., \& Højlund, S. (2005). Materialitetens pædagogiske kraft. In K. Larsen (Eds.), Arkitektur krop og læring (pp. 21-43). København: Hans Reitzels Forlag.

Hacking, I. (1991). The Making and Molding of Child Abuse. Critical inquiry. 17, 253-288.

Ingold, T. (2000). Building, dwelling, living: How animals and people make themselves at home in the world In T. Ingold, The perception of the environment: Essays on livelihood, dwelling and skill (pp.172-189). London \& New York: Routledge.

Jacobsen, M. H. (2007): I samfundets sprækker. Aalborg: Aalborg Universitetsforlag.

Jørgensen, A. (2006). Når kvarteret opdager sig selv. Aalborg: Aalborg Universitetsforlag.

Kirkeby, I. M., Gitz-Johansen, T., \& Kampmann J. (2005). Samspil mellem fysisk rum og hverdagsliv i skolen. In K. Larsen (Eds.), Arkitektur krop og læring (pp. 43-69). København: Hans Reitzels Forlag.

Kristensen, H. (2008). Huset som ramme om vore liv. In L. S. Henriksen et al (Eds.), Sociologiens rum - Festskrift for Jens Tonboe (pp. 95-113). Aalborg: Aalborg Universitetsforlag.

Latour, B. (1992): Where are the Missing Masses? The Sociology of a Few Mundane Artifacts. In Bijker, E. \& J. Law (Eds.), Shaping Technology/Bulding Society. Studies in Socialtechnical Change. Cambridge, MA: The MIT Press.

Latour, B. (1996a). On Actor-network Theory. A few Clarifications. Soziale Welt, 47, 369-381. Latour, B. (1996b). On Interobjectivity. Mind, Culture and Activity, 3, 228-246.

Martinsen, K. (2005): At bo på sygehus og erfare arkitektur. In K. Larsen (Eds.), Arkitektur krop og læring (pp. 131-159). København: Hans Reitzels Forlag.

Schutz, A. (2005). Hverdagslivets sociologi. En tekstsamling. København: Hans Reitzels Forlag. 
Strauss, A. (1975). Chronic illness and the quality of life. Saint Louis: The C. V. Mosby Company.

Sundhedsstyrelsen (2008). Vejledning om adgang til vederlagsfri fysioterapi. http://www.sst.dk/ publ/Publ2008/Plan/Fysio/VejlVederlagsfriFysioterapi_4jul08.pdf. Besøgt den 1. oktober 2011.

Tonboe, J. (1993). Rummets sociologi. København: Akademisk Forlag.

Williams, A. (2002). Changing geographies of care: employing the concept of the therapeutic landscapes as a framework in examining home space. Social science and medicine , 55, 141-154.

Winther, I. W. (2005). Hjemmeregler: hvordan hjem gennem regler bliver en inklusiv eksklusivitet. In K. Larsen (Eds.), Arkitektur krop og læring (pp. 223-241). København: Hans Reitzels Forlag. 


\section{Abstracts in English}

\section{Aesthetics, health and illness}

\section{Regner Birkelund}

The article highlights the importance for health and illness, which has been ascribed to aesthetics in different historical periods. The starting point is ancient Greece where the belief in the positive impact of aesthetics on health and illness was manifested in the architectural decor and artistic embellishments of the numerous medical sanctuaries. In addition, the article underlines the way in which key philosophers within the phenomenological tradition connected the aesthetic impression to health-based life phenomena such as love of life, courage for life and well-being. A line is drawn from the historical and phenomenological perspective on aesthetics and health to more recent research which confirms the positive impact of aesthetic impressions. 


\title{
The medical "mealspace": Is the architecture overlooked or forgotten here?
}

\author{
Tenna Doktor Olsen Tvedebrink, Anna Marie Fisker \& Poul Henning \\ Kirkegaard
}

Today the term 'hospital' is commonly used about the public space where the patients are examined and treated. However, being cured from sickness is often not only a matter of medical or surgical treatments, but a matter of the entire 'medical space' of care and caring established around the patient for instance with meals and nursing during hospitalization. But it is also, we would like to argue, about the architecture; the house framing the entire space. With this article, and on the background of the project MORE, we would like to study the connection between sickness, meals, and architecture. Methodologically, we take our point of departure in the theory on the elements of architecture developed by the architect Gottfried Semper, who back in the late 19th century formed the basis for the contemporary and modern architectural-theoretical definition of "space" as experienced phenomenon. On the background of Semper's theoretical framework and based on the description of a patient meal from the renaissance hospital Santa Maria Nouva, we provide an example of how the architecture of the "mealspace", through an intentional staging of the meal rituals together with the medical treatments, was an essential part of the 'medical space'. Even though this scenario seems theatrical today, we think, that this historical description could contribute to a greater understanding of the 'medical space' and the design of hospital architecture in the future. With this article we, as such, wish to argue for a stronger focus on the architecture of the "mealspace" in the future hospitals, as well as in research related the 'medical space'.

\section{The spatiality of the meal - an arena for health promotion?}

\author{
Rikke Nygaard, Mia Brandhøj, Camilla Berg Christensen \& Bent Egberg \\ Mikkelsen
}

This article wishes to break with a reductionist approach to the understanding of food and meals seen only as a question of nutrition and contribute, rather, to the 
development of a new and broader analytical framework which is able, to a greater extent, to apprehend the interaction between food, meals and health in order to be able to identify potentially unexploited spaces for health promotion. In this article we focus on some of the 'foodscape studies' which have recently emerged within the scientific literature around the area of food and meals. Foodscapes provides an interesting analytical framework, as it offers an insight into the complex interaction between availability, actors - including those eating, those selling and those serving - and with the physical environment in which our choice of meal is made. In our research in public health nutrition and meal science we are investigating how this analytical framework can be applied to the meals that surround us in our everyday lives outside of the domestic sphere. In this article we look at a number of the most important contributions from the foodscapes literature and offer a model, which aims at operationalizing analyses with a foodscapes approach for the purposes of making this complex approach more manageable in specific analyses. In order to exemplify how this can be done, the possibilities of the model are demonstrated in our work with health promoting spaces, specifically with cases from vocational schools and from the bus driver business.

\section{Entering 'Sacred Space'. On Chaplaincy Care in Danish Hospitals}

\section{Hanne Bess Boelsbjerg}

In Danish hospitals spiritual care is offered by chaplains to all patients, irrespective of whether or not the patient is religious. This article explores the room in which such spiritual care is provided. Presenting insights from interviews with 15 chaplains of Muslim or Christian faith together with an observation of a conversation between a Christian chaplain and a patient, the article seeks to devel-op a contextual understanding of how spiritual care is provided. The article argues that the chaplain uses rituals and metaphors to demarcate the boundaries of an invisible space used for meaning-making. If the chaplain and the patient establish a trustworthy relationship, the use of rituals can create a sense of 'sacred space.' This analytic term is used to help us visualize the invisible room where patients have the opportunity to re-evaluate their beliefs and values. The concept of 'sacred space' draws on the theories of Emile Durkheim, Victor Turner and Gregory Bateson. It relies on the concept of non-communication. Although it cannot be ut- 
tered, some of the understanding of this 'sacred space' can be turned into a flexible metaphor understood in different ways by both chaplain and patient. Through a negotiation between the different understandings of reality the patients may experience a support as they see themselves as more than severely ill bodies.

\section{Illness and self-image across spaces}

\section{Iben Emilie Christensen \& Sofie Ilsvard}

This article deals with the relationship between physical spaces, illness and selfimage amongst people with severe physical disabilities or impairment of function, who have been prescribed gratuitous physiotherapy as part of their treatment. The study has been based on field-work conducted within the framework of a phenomenological-hermeneutical approach, with the pivotal theme pertaining to the subjective and beneficial experiences of the participants, as well as identifying ways for participants to integrate the institutional frame of the clinic of physiotherapy as an integral part of their everyday lives. Despite the fact that participants are typically engaged in lifelong treatments in clinics of physiotherapy, the existing knowledge of their experience hereof, is quite sparse. The aim of the article is therefore to gain insight into the participants lived experiences of training within the environment of the physiotherapeutic clinic - thus to examine the significance of physical space in relation to the self-image of the participants. The empirical analysis is established on a relational perspective, as the participants address both their perception of illness and self-image dependent on their location during treatment, and on their subjective spatial understanding. In this context it is argued that the definition and understanding of physical space in relation to the participants' self-images emerge and become visible through the comparison and interpretation of other various physical spaces. In examining the self-image of patients, the paradoxical conclusion arises that the clinic of physiotherapy, a place where illness is treated and practiced, is not experienced by participants as a 'space of illness', but as a much-needed free space from illness where they feel like 'regular people'. In contrast to this are the private homes and the public space, which are far more likely to represent a 'space of illness', as these are the spaces where impaired function and disability create barriers for the participants' social lives and where the limits between normalcy and deviance are defined. 


\section{Taming pleasure - a spatial analysis of a Danish heroin clinic}

Birgitte Schepelern Johansen E Katrine Schepelern Johansen

Substance abuse treatment with medically prescribed heroin is new in a Danish context. This article addresses the complicated transformation of heroin from illegal street drug to prescribed medicine through an analysis of the spatial arrangements in one of the five new clinics in Denmark. The article shows how the heroin clinic stages this modelling of heroin as medicine through certain spatial arrangements and means of control with the aim of separating the heroin from the street culture it has been part of before and from the pleasure that the users are striving for. The goal of this process is to marginalise the heroin from the life of the users. At the same time the analysis reveals how the heroin embed other possible presences - as social taboo, as illegal drug, as pleasure - and these other presences constantly surfaces in the ideals of the staff and in the behaviour of the clients: in their high and their ways of appropriating space. Thus, the heroin should be understood as a 'messy object' that makes the space for treatment inevitably contradictory.

\section{Environmental qualities and patient well-being in hospital settings}

\section{Anne Kathrine Frandsen}

Within the last decades the impacts of the physical environments of hospitals on healing and health-care outcomes have been subject to ample research. The amount of documentation linking the design of physical environments to patient and staff outcomes is increasing.

A Danish research project undertaken by Architecture and Design and the Danish Building Research Institute (Aalborg University) set out in 2008 to review research on the impact of the environmental qualities of health-care facilities on patients and staff. The objective of the review team was to develop a tool that would allow an overview of this research, needed by construction clients and decision-makers in Denmark responsible for large investments in future hospitals and healthcare environments in the decade to come. 
The present paper offers an overview of the findings of the review team. Its point of departure is the categorisation developed during the study, which facilitated the sorting and communication of the findings. In this categorisation, research findings are grouped according to their focus on specific spatial qualities - such as light and acoustics - and not according to the different diagnoses, which may be linked to such spatial qualities, like stress and depression. In other words, the application of this categorisation foregrounds the importance and the convenience of looking at spatial qualities of the physical environment, when addressing issues related to patient or staff wellbeing.

Indenfor de sidste 20 år har der været en voksende forskningsmæssig interesse for hospitalers fysiske rammer og disses betydning for patienters velvære og helbredelsesforløb, samt personalets velbefindende. Tilsvarende er antallet af forskningsresultater, der knytter udformningen af de fysiske rammer på hospitaler sammen med patienters og personalets velbefindende, stigende.

I 2008-09 gennemførte Arkitektur og Design og Statens Byggeforskningsinstitut ved Aalborg Universitet et litteraturstudium af den forskning, der undersøger om og hvordan kvaliteter ved de fysiske rammer påvirker patienter og personale. Målet med litteraturstudiet var at udvikle et værktøj, der kunne give bygherrer og beslutningstagere med ansvar for byggeriet af de mange nye hospitaler i Danmark, et overblik over forskningen på feltet.

Denne artikel søger at give et overblik over litteraturstudiets resultater. Dette gøres med udgangspunkt i en kategoriseringsmodel, udviklet som en del af studiet med henblik på at sortere og kommunikere de iagttagne forskningsresultater. I modellen kategoriseres forskningsresultaterne ud fra, hvilke faktorer i de fysiske rammer, de beskriver - f.eks. lys og akustik - og ikke ud fra de diagnoser, som disse faktorer kan sættes i forbindelse med - f.eks. stress og depression. Ved at kategorisere den iagttagne forskning med udgangspunkt i denne model, fremhæves de kvaliteter ved hospitalernes fysiske rammer, som synes at spille en rolle for patienters og personalets velbefindende. 


\section{Forfatterliste}

\section{Regner Birkelund}

Cand.cur., ph.d. og dr.phil. Lektor ved Institut for Folkesundhed, Aarhus Universitet. Har publiceret en lang række bøger og artikler, der bl.a. har æstetikkens betydning for sundhed, velvære og erkendelse som omdrejningspunkt. Senest har han udgivet antologien Ved livets afslutning, i hvilken æstetikkens betydning i forbindelse med palliativ omsorg, pleje og behandling belyses.

\section{Tenna Doktor Olsen Tvedebrink}

Phd-studerende i «Hospital Mealscape Design» ved Institut for Byggeri \& Anlæg, Aalborg Universitet. Uddannet civilingeniør med speciale i Arkitektur, fra Institut for Arkitektur \& Design ved Aalborg Universitet, og er enkeltfagsstuderende fra Københavns Universitet, Institut for Fødevareforskning og Institut for Humanernæring. Forskningsområder er arkitektur, design, interiør, spisemiljøer, måltider og madhistorie.

\section{Anna Marie Fisker}

Lektor ved Aalborg Universitet, sektionsleder af sektionen Food+Design, Institut for Byggeri og Anlæg, Aalborg Universitet. Uddannet arkitekt maa fra Århus Arkitektskole og er PhD i «Mad og Arkitektur» fra Aalborg Universitet, Institut for Arkitektur, Design og Medie Teknologi. Forskningsområder er arkitektur, design, interiør, madkultur, gastronomi, måltider og madhistorie.

\section{Poul Henning Kirkegaard}

Professor ved Aalborg Universitet, Institut for Byggeri \& Anlæg. Uddannet civilingeniør med speciale i bygningskonstruktion og er PhD i «Optimal Design of Measurement Programs for the Parameter Identification of Dynamic Systems». Forskningsområder er 
blandt andet rumakustik, arkitektonisk kvalitet, digital arkitektur, bærende konstruktioner, bygningsmaterialer og integreret design.

\section{Rikke Nygaard}

Rikke Nygaard forfølger i denne artikel en tidligere interesse i hverdagslivsperspektiver på sundhed og sundhedsfremme og hverdagslivet som arena for læring. Og hvor hun tidligere har arbejdet med forældreskabet, seksualitet og køn forfølger hun i denne artikel via et Foodscapes perspektiv maden, måltidet og arbejdslivet som specielt egnede arenaer for sundhedsfremme.

\section{Mia Brandhøj}

Mia Brandhøj har etableret både forsknings- og praksis- erfaring med at implementere sundhedsfremmende indsatser på små- og mellemstore danske arbejdspladser, gennem tværvidenskabelig tilgange i forskningsprojekter og som konsulent i branchen. Mias særlige interesse i Foodscapes studierne og litteraturen er blevet udbygget i litteraturgennemgang, Ph.d. kursus, rapport og nu i denne artikel.

\section{Camilla Berg Christensen}

Camilla Berg Christensen har primært arbejdet med kost- og motions-vaner blandt unge. Camilla har en speciel interesse i sundhedsfremmende indsatser på ungdomsuddannelser i et interventionsorienteret perspektiv. I denne artikel udforskes Foodscapes tilgangen i forhold til hvordan et sådan perspektiv kan berige arbejdet med sundhedsfremmende indsatser på ungdomsuddannelserne.

\section{Bent Egberg Mikkelsen}

Professor, Ph.D, Forskningskoordinator, Kandidat i levnedsmiddelvidenskab (cand. brom.), 1984, PhD i Sociologi, RUC, TekSam. Forsker i ernæring og bæredygtigt forbrug i udespisningen, særligt skoler, børnehaver, arbejdspladser og sygehuse. Har særlig fokus på participatorisk udvikling af interventioner samt på måling af effekter af interventioner og strategier. Indtager og har indtaget en række ekspertfunktioner for en række internationale organisationer i spørgsmål om folkesundhedsernæring og settings, herunder Europarådet, WHO og EU kommisionen. Co editor på tidsskriftet Public Health Nutrition.

\section{Hanne Bess Boelsbjerg}

Hanne Bess Boelsbjerg (1973) er cand.mag. i religionsvidenskab (AU). Fra 2006 tilknyttet Center for Forskning i Eksistens og Samfund, Sociologisk Institut, Københavns Universitet. Siden 2010 ph.d.-stipendiat ved forskningsenheden 'Helbred, Menneske og Samfund' på Institut for Sundhedstjenesteforskning på Syddansk Universitet. Hendes ph.d.-projekt omhandler kristne og muslimske kræftpatienter i palliative forløb. 


\section{Iben Emilie Christiensen}

Iben Emilie Christensen er uddannet cand.scient.soc. fra Institut for Sociologi, Socialt Arbejde og Organisation, Aalborg Universitet, i 2011. Iben er projektleder i KORA, Det Nationale Institut for Kommuners og Regioners Analyse og Forskning (tidligere Dansk Sundhedsinstitut), hvor hun ved hjælp af kvalitative metoder inddrager og kombinerer borgeres og fagpersoners erfaringer med $f x$ forebyggelsesindsatser og behandling $i$ sundhedsvæsenet.

\section{Sofie Ilsvard}

Sofie Ilsvard er uddannet cand.scient. soc. fra Institut for Sociologi, Socialt arbejde og Organisation, Aalborg Universitet, i 2011. Sofie er ansat som videnskabelig assistent ved Sektion for Almen Medicin, Institut for Folkesundhed, Aarhus Universitet, og forsker i deltagelse og rekruttering ved forebyggelsesindsatser.

\section{Birgitte Schepelern Johansen}

Birgitte Schepelern Johansen er ph.d., adjunkt ved Minoritetsstudier, Institut for Tværkulturelle og Regionale Studier, Københavns Universitet. Hun er religionssociolog af uddannelse, men har gennem en årrække primært arbejdet med forholdet mellem normalitet og afvigelse i et videnssociologisk perspektiv.

Katrine Schepelern Johansen Katrine Schepelern Johansen er ph.d. i antropologi og ansat som projektleder ved KORA (Det Nationale Institut for Kommuner og Regioners Analyse og Forskning). Hendes pri- mære forskningsinteresse er psykiatri og stofmisbrugsbehandling og hun har senest arbejdet med en evaluering af det danske tilbud om lægeordineret heroin.

\section{Anne Kathrine Frandsen}

Anne Kathrine Frandsen er arkitekt og Ph.d. fra Kunstakademiets Arkitektskole. I dag er hun ansat på Statens Byggeforskningsinstitut, Aalborg Universitet, hvor hun dels forsker i byggeprocesser og implementering af ny viden og teknologi i design- og byggeprocesser, dels i oplevet kvalitet i arkitektur. 